\title{
APPROACHES TO SUSTAINABLE RURAL DEVELOPMENT IN A PREDOMINANTLY NON-RURAL REGION
}

\author{
Vasily Erokhin ${ }^{1}$
}

\begin{abstract}
Summary
Paper aims at investigation of contemporary approaches to sustainable rural development in Russia with focus on predominantly non-rural areas, gravitationally attracted by such urban agglomerations, as Moscow. It includes the overview of current experiences in rural development, analysis of major economic and social indicators of rural areas in comparison with urban ones, characteristic of specific features of rural areas in Moscow Oblast, and elaboration of perspective ways to ensure sustainable development of those areas. Methods of benchmarking analysis, SWOT-analysis and program prognosis are implemented. The major results of the current research are discoveries of growth points for rural development and recommendations on perspective measures of state and local policies in rural areas, directed on increase of living standards of rural population and retention of labour resources in their traditional rural areas of inhabitation.
\end{abstract}

Key words: sustainable rural development, region, rural areas, urban agglomeration

JEL: $Q 18, P 25$

\section{Introduction}

Rural development, aimed at improvement of quality of life, is the key factor of sustainable growth of agricultural production effectiveness, as well as social stability in rural areas. Agriculture, as the primary industry in rural areas, is the major (and often the only one) source of employment and income for rural people. It directly influences economic, social, and demographic processes in rural territories, affects land settlement and reclamation, and ensures maintenance of territorial and cultural integrity of the country (Ivolga, Uryadova, 2010).

Consequently, state policy in the sphere of agriculture should be proceeded from sustainable development of rural areas, based on economic, social, and environmental approaches. One of the major threats to effectiveness of state policies in rural areas is the contrast between attractions of city life and negative appeals of rural life. State support and budget subsidies are necessary to decelerate stagnation, but not enough to ensure long-term sustainable development. People, attracted by higher living standards in urban areas, tend to leave

1 Ph.D., Department of Management and Marketing, Moscow University of Finance and Law, 8, build. 1, Presnenskaya Embankment, 115114 Moscow, Russia, Phone: +74999951963, E-mail: basilic@list.ru 
traditional rural areas of inhabitation in favour of bigger urban agglomerations. In order to prevent this negative tendency and retain labour resources in rural areas, the state policy should be reoriented from the exclusively economic approach to a combination of economic, social, environmental, and cultural factors.

That is especially relevant for areas contiguous to big cities. On the face of it, such predominantly non-rural areas are in the better position in comparison to the rural ones, since the major economic indicators (income level, labour inflows, employment rates, etc.) are higher. However, that is primarily because of employment opportunities in the spheres, not related to agriculture (trade, services, etc.) or commuting of people from surrounding rural settlements to urban centres. In such a situation sustainable development of traditional agricultural production and rural way of life is even in a bigger danger, despite the higher attractiveness of those "pseudo-rural" areas. That is why the above-mentioned complex approaches should be applicable to the predominantly non-rural areas as well, in order to provide diversified and multipolar development pathways.

As the part of the current research we have studied the contemporary experience of Russia in the sphere of rural development in general, and the case of Moscow Oblast in particular. The region surrounds the biggest Russia's urban agglomeration of Moscow City (over 12 mln people as of 2014), which is the absolute centre of gravitational attraction for labour resources from its rural areas. Additionally to the overview of the contemporary state of rural areas in Russia (population, employment, income, etc.), we have investigated specifics of "urban-oriented" rural areas, discovered the major threats and challenges of their sustainable development, and elaborated the set of relevant perspective measures.

\section{Material and Methods}

For the purposes of the current research we have primarily addressed the works by Russian and foreign researches and experts, related to analysis of local specifics of rural development and unique economic, social and environmental features of certain regions (Merzlov et al., 2012; Rusinova, 2011; Lavrukhina, 2013; Vuković et al., 2012; Wiggins, Proctor, 2001).

We have also studied approaches to sustainable rural development through small and medium entrepreneurship in rural areas and intensification of agricultural production (Bondarenko, 2011; Trukhachev, Lescheva, 2010). The special attention was paid to integration of agricultural producers (Lescheva, 2007; Lescheva, 2008) and diversification of income opportunities in rural areas by means of alternative employments, rural tourism and related activities (Ivolga, Erokhin, 2013; Jelocnik, Ivolga, 2012; Ivolga, Belak, 2013; Kundius, Chermyanina, 2011; Ivolga, Mikhaylova, 2013).

International practices and success stories in the sphere of rural development had been obtained from the works of W. Heijman (regional competitiveness and regional issues of economic development), (Heijman, Schipper, 2010; Heide, Heijman, 2012; Bronisz et al., 2008), J. Andrei (cases of Eastern Europe in general and Romania in particular), (Erokhin, Ivolga, Andrei et al., 2014) and D. Cvijanovic and P. Vuković (investigations of perspectives of rural tourism in separate localities of Serbia and other Danube countries) (Cvijanovic, Vukovic, 2012). 
Data are obtained from the reports of the Federal Service of State Statistics of the Russian Federation, Ministry of Agriculture of the Russian Federation, Ministry of Economic Development of the Russian Federation, administrative bodies of Moscow Oblast, related to agricultural production and rural policies (Ministry of Agriculture and Food Production of Moscow Oblast).

\section{Results and Discussion}

Rural population in Russia accounts $37.1 \mathrm{mln}$ people, which is about $26 \%$ of total population. Working-age rural population is $21.4 \mathrm{mln}$ people. There are 153.1 thousand settlements located in rural territories; over 133.7 thousands of them are permanently inhabited. Herein, $73 \%$ of rural settlements have less than 200 inhabitants, while settlements with over two thousand residents account only 2\% (State Council of the Russian Federation, 2014).

Despite the serious structural changes, economic and social conditions of rural areas in Russia remain complicated. Levels of unemployment and poverty are twofold higher in comparison to urban areas; while rural labour compensations are twofold lower than the ones in other industries. Small and medium farming is being developed slowly; rural economy stays sector-specific; recreational potential is underutilized. Because of lower living standards, existing infrastructural problems and high unemployment people migrate to urban areas (Table 1). Number of rural settlements in 2010 (the latest census) decreased on 9.2 thousand in comparison to 1989, while the number of depopulated rural settlements increased twofold from 9.4 thousand up to 19.4 thousand. According to the All-Russian research institute of rural economy (VNIIESH), over one third of rural people consider an opportunity to leave rural areas in favour of cities. Among young people that share is even bigger - up to a half (Bondarenko, 2011).

Table 1. Number of rural inhabitants in Russia in 2000-2013, thousand people.

\begin{tabular}{|l|r|r|r|r|r|r|}
\hline & \multirow{2}{*}{ Years } & \multirow{2}{*}{$\begin{array}{c}\text { Population, begin- } \\
\text { ning of the year }\end{array}$} & \multirow{2}{*}{$\begin{array}{c}\text { gross } \\
\text { increase }\end{array}$} & \multicolumn{4}{|c|}{$\begin{array}{c}\text { Variation }(+,-): \\
\text { including: } \\
\text { Population, } \\
\text { increase }\end{array}$} & $\begin{array}{c}\text { nigration } \\
\text { increase }\end{array}$ & $\begin{array}{c}\text { territorial trans- } \\
\text { end of the year } \\
\text { formations }\end{array}$ \\
\hline 2000 & 39470.6 & -238.7 & -274.2 & -2.6 & 38.1 & 39231.9 \\
\hline 2001 & 39231.9 & -307.9 & -271.7 & -51.9 & 15.7 & 38924.0 \\
\hline 2002 & 38924.0 & -281.6 & -281.9 & -26.7 & 27.0 & 38642.4 \\
\hline 2003 & 38642.4 & -348.3 & -281.5 & -90.5 & 23.7 & 38294.1 \\
\hline 2004 & 38294.1 & 324.8 & -260.3 & -108.8 & 693.9 & 38618.9 \\
\hline 2005 & 38618.9 & -200.9 & -287.6 & -117.4 & 204.1 & 38418.0 \\
\hline 2006 & 38418.0 & -287.0 & -230.4 & -109.0 & 52.4 & 38131.0 \\
\hline 2007 & 38131.0 & -248.6 & -145.7 & -50.9 & -52.0 & 37882.4 \\
\hline 2008 & 37882.4 & -60.7 & -113.3 & -60.6 & 113.2 & 37821.7 \\
\hline 2009 & 37821.7 & -49.6 & -88.9 & -47.8 & 87.1 & 37772.1 \\
\hline 2010 & 37772.1 & -327.9 & -81.7 & -228.8 & -17.4 & 37444.2 \\
\hline
\end{tabular}




\begin{tabular}{|c|c|c|c|c|c|c|}
\hline \multirow{3}{*}{ Years } & \multirow{3}{*}{$\begin{array}{l}\text { Population, begin- } \\
\text { ning of the year }\end{array}$} & \multicolumn{4}{|c|}{ Variation $(+,-)$ : } & \multirow{3}{*}{$\begin{array}{l}\text { Population, } \\
\text { end of the year }\end{array}$} \\
\hline & & \multirow{2}{*}{$\begin{array}{c}\text { gross } \\
\text { increase }\end{array}$} & \multicolumn{3}{|c|}{ including: } & \\
\hline & & & \begin{tabular}{c|} 
natural \\
increase
\end{tabular} & $\begin{array}{c}\begin{array}{c}\text { migration } \\
\text { increase }\end{array} \\
\end{array}$ & $\begin{array}{c}\text { territorial trans- } \\
\text { formations }\end{array}$ & \\
\hline 2011 & 37444.2 & -129.8 & -42.5 & -149.9 & 62.6 & 37314.4 \\
\hline 2012 & 37314.4 & -85.6 & -6.3 & -166.6 & 87.3 & 37228.8 \\
\hline 2013 & 37228.8 & -110.6 & -0.8 & -176.8 & 67.0 & 37118.2 \\
\hline
\end{tabular}

Source: State Council of the Russian Federation, 2014.

That is not exclusively Russia's situation. Similar processes are observed in other countries. For example, USA and EU countries lose up to 5\% of their rural population within 3-5 years (Lavrukhina, 2013). Low status value of rural life, high risks of agricultural production, and poor perspectives of rural activities in terms of career development and income lead to migration of people from rural areas worldwide. Over the last 14 years the number of rural inhabitants in Russia decreased on $2.4 \mathrm{mln}$ people, whilst losses because of natural and migration factors were $3.8 \mathrm{mln}$ people. Population decline was mainly caused by excess of mortality over fertility (63\%). Activation of demographic policy in recent years decreased natural decline in the population. However, migration outflow grew substantially and became the main reason of depopulation in rural areas.

Nowadays problem of depopulation is the most severe in Kostromskaya, Tverskaya, Yaroslavskaya, Vologodskaya, Pskovskaya, Kirovskaya, and Magadanskaya oblasts. Over one fifth of rural settlements in those regions are depopulated and deserted (Merzlov et al., 2012). Only 18 regions of Russia out of 83 had migration increase in 2013. Four regions resulted with the coefficients of migration increase over 70: Kurskaya, Leningradskaya, Yaroslavskaya, and Moskovskaya oblasts.

Structure of economically active population in rural areas in 2012-2013 was improved; share of unemployed people revised from $9.6 \%$ in 2012 down to $8.5 \%$ in 2013 (Table 2).

Table 2. Economic activity and employment of rural population in Russia in 2012-2013, thousand people.

\begin{tabular}{|c|c|c|c|c|}
\hline Indicator & 2012 & 2013 & $\begin{array}{c}\text { Varia- } \\
\text { tion } \\
(+,-)\end{array}$ & $\begin{array}{l}2013 \text { to } \\
2012, \%\end{array}$ \\
\hline Total population, the 15 to 72 age bracket, thousand people & 27524 & 27524 & - & 100.0 \\
\hline Economically active population, thousand people & 18100 & 18081 & -19 & 99.9 \\
\hline \multicolumn{5}{|l|}{ including: } \\
\hline employed, thousand people & 16561 & 16579 & 18 & 100.1 \\
\hline employed, \% & 91.5 & 91.7 & 0.2 & \\
\hline unemployed, thousand people & 1540 & 1502 & -38 & 95.7 \\
\hline unemployed, \% & 8.5 & 8.3 & -0.2 & \\
\hline Inactive population, thousand people & 9424 & 9443 & 19 & 100.2 \\
\hline
\end{tabular}

Source: State Council of the Russian Federation, 2014. 
In 2000-2013 employment in rural areas was essentially lower in comparison to cities. There is an overall growth of employment rate, observed both in rural and urban areas in 20002013, however the growth rate for urban areas is threefold bigger, than in the rural ones. Employment rate for urban areas in 2013 gained 7.5 percentage points in comparison with 2000, while the one for rural areas - only 2.4 (Figure 1).

Figure1. Employment levels in rural and urban areas of Russia in 2000-2013, \%.

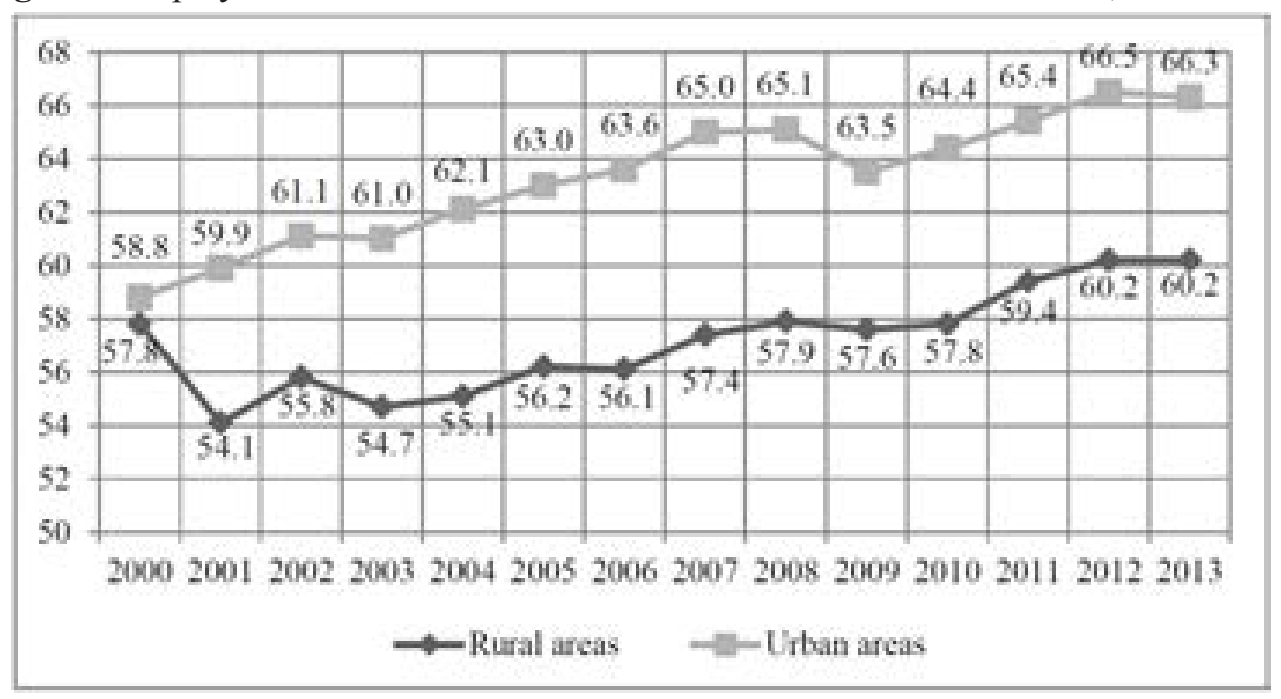

Source: State Council of the Russian Federation, 2014.

Level of employment decreased in North-Caucasus and Privolzhsky federal districts to the utmost. North-Caucasus federal District has the highest unemployment rate $-14.3 \%$. Unemployment levels in rural areas of Siberian and Far East federal districts exceed international standards as well (Table 3).

Table 3. Number of unemployed people and overall level of unemployment in rural areas of Russia, average of reference period.

\begin{tabular}{|l|r|r|r|r|r|r|}
\hline \multirow{2}{*}{ Federal district } & \multicolumn{3}{|c|}{$\begin{array}{c}\text { Number of unemployed } \\
\text { people, thousand people }\end{array}$} & \multicolumn{2}{c|}{ Level of unemployment, \% } \\
\cline { 2 - 7 } & $\mathbf{2 0 1 2}$ & $\mathbf{2 0 1 3}$ & $\begin{array}{r}\mathbf{2 0 1 3} \text { to } \\
\mathbf{2 0 1 2} \mathbf{\%}\end{array}$ & $\mathbf{2 0 1 2}$ & $\mathbf{2 0 1 3}$ & $\begin{array}{l}\text { Variation } \\
\text { (+,-), p.p. }\end{array}$ \\
\hline Russia, total & 1540 & 1502 & 97.5 & 8.5 & 8.3 & +0.2 \\
\hline Central Federal District & 184 & 190 & 103.0 & 5.3 & 5.4 & 0.1 \\
\hline North-West Federal District & 90 & 87 & 96.7 & 7.9 & 7.9 & 0.0 \\
\hline South Federal District & 199 & 203 & 102.0 & 8.0 & 8.2 & 0.2 \\
\hline $\begin{array}{l}\text { North-Caucasus Federal } \\
\text { District }\end{array}$ & 354 & 326 & 92.1 & 15.8 & 14.3 & -1.5 \\
\hline Privolzhsky Federal District & 281 & 264 & 94.0 & 6.6 & 6.2 & -0.4 \\
\hline Ural Federal District & 107 & 86 & 80.4 & 9.1 & 7.3 & -1.8 \\
\hline Siberian Federal District & 241 & 259 & 107.5 & 9.5 & 10.3 & 0.8 \\
\hline
\end{tabular}




\begin{tabular}{|c|r|r|r|r|r|r|}
\hline \multirow{2}{*}{ Federal district } & \multicolumn{3}{|c|}{$\begin{array}{c}\text { Number of unemployed } \\
\text { people, thousand people }\end{array}$} & \multicolumn{2}{c|}{ Level of unemployment, \% } \\
\cline { 2 - 7 } & $\mathbf{2 0 1 2}$ & $\mathbf{2 0 1 3}$ & $\begin{array}{r}\mathbf{2 0 1 3} \text { to } \\
\mathbf{2 0 1 2 ,} \%\end{array}$ & $\mathbf{2 0 1 2}$ & $\mathbf{2 0 1 3}$ & $\begin{array}{r}\text { Variation } \\
\text { (+,-), p.p. }\end{array}$ \\
\hline Far East Federal District & 84 & 87 & 103.6 & 10.9 & 11.0 & 0.1 \\
\hline
\end{tabular}

Source: State Council of the Russian Federation, 2014

Income gap between urban and rural territories is permanent over the referred period of 2000-2013-about 150\% (Figure 2). Absolute amounts of per capita disposable incomes had been considered based on data of the State Council of the Russian Federation, 2014, adjusted for inflation (Rosstat, 2014) and recalculated in Euro (Central Bank of the Russian Federation, 2014). Despite its growth over the referred period, income level for rural areas is still very low. The linear trend developed to 2015 hardly reaches $€ 350$, while an average disposable income in urban areas is expected to excess $€ 550$ in 2015.

Figure2. Dynamics of average per capita disposable income in rural and urban areas of Russia in 2000-2013 and liner trends to 2015, euro per month.

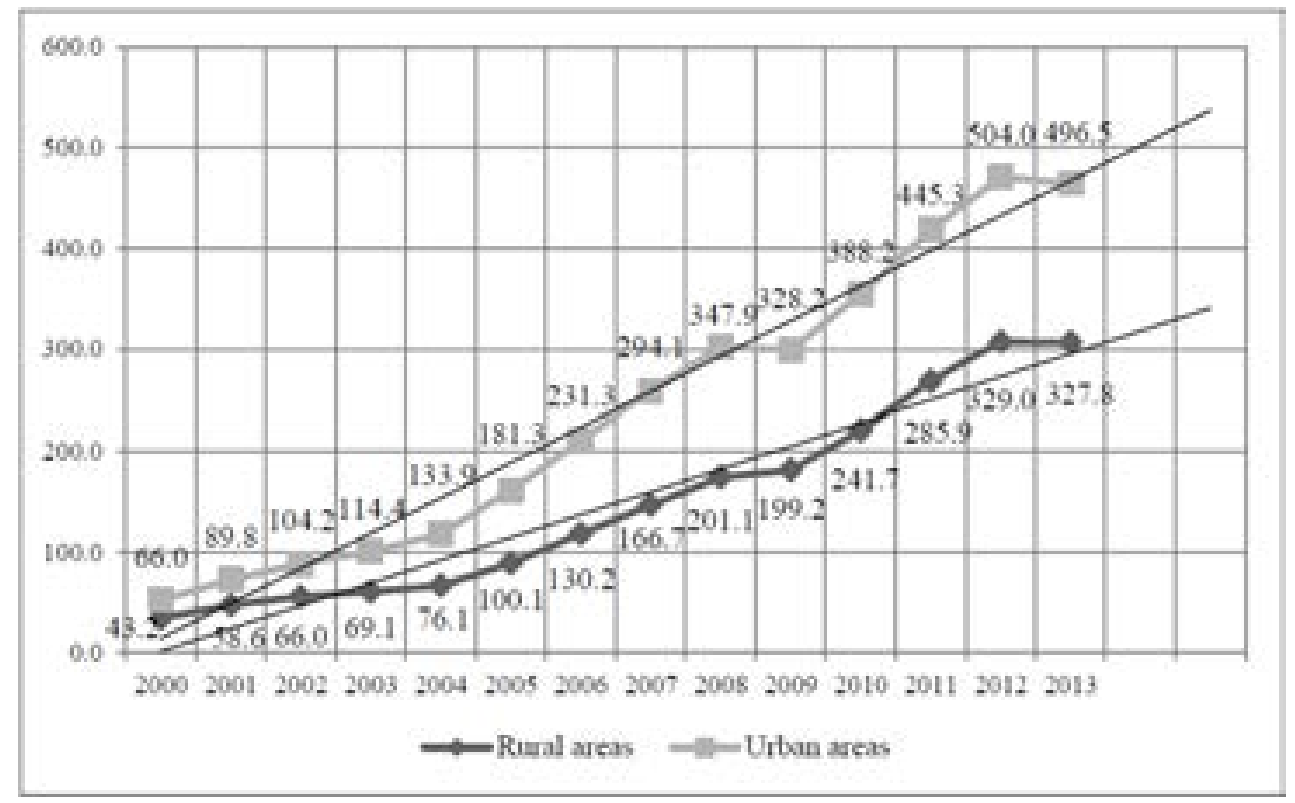

* Presented financial numbers are real, inflation is considered (Rosstat, 2014). All financial numbers are calculated in Euro based on average Euro-Ruble ratios for each year.

Source: Author's development based on (State Council of the Russian Federation, 2014; Rosstat, 2012; Rosstat, 2014; Central Bank of the Russian Federation (2014)).

Overcoming differences between urban and rural areas in income level in particular and in economic, technological, and social development in general should become the strategic trend of rural policy in Russia. People will migrate back to rural areas from cities only in case they are aware of certain level of income, as well as infrastructure, comparable to urban conditions. 
As of today, almost a half of regions in Russia (47\%) are not favourable for sustainable rural development. Some of the regions are even considered as depressed ones, with various symptoms of economic downturn and social depression. Those regions concentrate about $64 \%$ of rural population of Russia (Merzlov et al., 2012).

According to the Agro2b Ranking (Agro2b, 2014), there are ten regions in Russia, which have more or less successful experiences in the sphere of rural development (Table 4). The research ranks regions on four sub-ratings (level of income, intensiveness of housing construction, quality of housing services and utilities, and access to nurseries and medical services in rural areas).

Table 4. Ranking of regions of Russia on quality of life in rural areas and level of rural development in 2013.

\begin{tabular}{|c|l|c|c|c|c|}
\hline \multirow{2}{*}{$\begin{array}{c}\text { Rating } \\
\text { position } \\
\text { (total) }\end{array}$} & \multicolumn{1}{|c|}{ Region } & $\begin{array}{c}\text { income } \\
\text { level }\end{array}$ & $\begin{array}{c}\text { housing } \\
\text { construction }\end{array}$ & $\begin{array}{c}\text { housing servic- } \\
\text { es and utilities }\end{array}$ & $\begin{array}{c}\text { nurseries and } \\
\text { medical ser- } \\
\text { vices }\end{array}$ \\
\hline 1 & Krasnodar Krai & 12 & 2 & 19 & 12 \\
\hline 2 & Leningrad Oblast & 2 & 4 & 32 & 14 \\
\hline 3 & Tula Oblast & 14 & 21 & 15 & 3 \\
\hline 4 & Moscow Oblast & 20 & 1 & 25 & 21 \\
\hline 5 & Belgorod Oblast & 1 & 9 & 8 & 50 \\
\hline 6 & Lipetsk Oblast & 8 & 31 & 6 & 32 \\
\hline 7 & Stavropol Krai & 13 & 24 & 7 & 35 \\
\hline 8 & Orenburg Oblast & 57 & 23 & 5 & 4 \\
\hline 9 & Samara Oblast & 56 & 19 & 12 & 9 \\
\hline 10 & Republic of Adygeya & 5 & 52 & 21 & 19 \\
\hline
\end{tabular}

Source: Agro2b, 2014.

It is worth noting that two regions of Russia, which are predominantly non-rural(Moscow and Leningrad oblasts), are still ranked among the leaders in rural development. Those regions are considered as attractive ones for incoming migration into their rural areas, with developed economic and social infrastructure, and high potential of rural development. According to A. Merzlov, Moscow and Leningrad oblasts have preconditions for development of rural areas of suburban type and poly-functional rural economy (Merzlov et al., 2012). Apart from most of the regions of Russia, they are characterized by high density of population in rural areas, developed transport, social and service infrastructure, high level of recreational utilization of available territories and resources, active housing construction, and high-productive farming (predominantly concentrated in big agricultural organizations and agri-industrial complexes). Moscow and Leningrad oblasts, occupying only $0.8 \%$ of overall territory of Russia, provide over $5 \%$ of national agricultural production. Potential of rural development in those areas is related to high migration attractiveness, proximity to the biggest economic centres of the country, easy access to urban infrastructures, better job opportunities in cities, developed and high-intensive agricultural production and food processing industries, and active involvement of local agricultural producers and processing companies into development of EP 2014 (61) 2 (291-306) 
rural infrastructure.

Moscow Oblast is the most advanced in Russia in terms of rural development and living standards of rural population. Rural population amounts to $18 \%$ of total population of the region, which is much lower, than in most of the regions of Russia. The average level of income in rural areas of Moscow Oblast is over $€ 600$, while the average level for Russia is about $€ 328$ (as calculated above). However, absolute amount is not always an indicator. If we compare the urban/rural income ratio, Moscow Oblast would be ranked only $20^{\text {th }}$ out of 83 regions of Russia. That is because of Moscow City with its one of the highest average levels of income in Russia (€1200). In comparison to that amount rural people in Moscow Oblast have only a half of that level. In terms of the urban/rural ratio, the leading region of Russia is Belgorod Oblast, the only one in the country, where average income in rural areas excesses the one of urban territories (Table 5).

Table 5. Ranking of regions of Russia on level of income in rural areas in 2013.

\begin{tabular}{|c|c|c|c|c|}
\hline \multirow{2}{*}{$\begin{array}{l}\text { Rating } \\
\text { position }\end{array}$} & \multirow[t]{2}{*}{ Region } & \multicolumn{2}{|c|}{$\begin{array}{l}\text { Average monthly nominal wages per } \\
\text { capita, euro }\end{array}$} & \multirow{2}{*}{$\begin{array}{l}\text { Agriculture / } \\
\text { economy ratio, } \%\end{array}$} \\
\hline & & all industries & agriculture & \\
\hline 1 & Belgorod Oblast & 471.86 & 492.23 & 104.32 \\
\hline 2 & Leningrad Oblast & 620.66 & 556.95 & 89.73 \\
\hline 3 & Tambov Oblast & 397.88 & 354.75 & 89.16 \\
\hline 4 & Kursk Oblast & 440.91 & 381.45 & 86.51 \\
\hline 5 & Republic of Adygeya & 394.32 & 340.61 & 86.38 \\
\hline 6 & Novgorod Oblast & 502.42 & 425.34 & 84.66 \\
\hline 7 & Republic of Mary El & 377.99 & 312.68 & 82.72 \\
\hline 8 & Lipetsk Oblast & 458.05 & 376.91 & 82.29 \\
\hline 9 & Penza Oblast & 451.20 & 366.81 & 81.30 \\
\hline 10 & Orel Oblast & 398.40 & 317.24 & 79.63 \\
\hline$\ldots$ & & & & \\
\hline 20 & Moscow Oblast & 842.18 & 605.42 & 71.89 \\
\hline
\end{tabular}

* Presented financial numbers are calculated in Euro based on average Euro-Ruble ratios for 2013.

Source: Author's development based on (Agro2b, 2014).

Agricultural production provides 3\% of GDP of Moscow Oblast. There are over 490 agricultural producers, 450 food processing enterprises, 6.6 thousand peasant farm enterprises, and 592 thousand rural households. Over 115.4 thousand people are involved into agricultural production, which is $8.2 \%$ of rural population of the region (Government of Moscow Oblast, 2012).

There is a special program adopted in Moscow Oblast in 2012, which is the Target program "Development of Agriculture and Regulation of Markets of Agricultural Commodities, Raw Materials and Food in 2013-2020" (Government of Moscow Oblast, 2012). The Program is aimed on complex development of local agri-industrial complex with allowances made for the recent Russia's accession into the World Trade Organization (WTO) and related 
transformations of external economic and trade environment. It included several subprograms, one of which is especially related to sustainable rural development (Subprogram V). It aims at three major directions:

1. Housing improvements in rural areas, provision of housing for young families and young professionals in order to retain them in rural areas, improve demographics, and provide local employers with labour of high qualification.

2. Development and promotion of extension services, information, consulting and legal support of rural population and local agricultural producers;

3. Infrastructural advancement of rural settlements (transport networks, housing and public utilities, medical services, social and cultural facilities, etc.), (Government of Moscow Oblast, 2012).

Government of the Moscow Oblast and local Ministry of Agricultural and Food targeted the following results to be achieved by 2020 :

1. Provision of rural population with major kinds of agricultural products and food in accordance with medical consumption criteria.

2. Growth of agricultural production on $30 \%$ by 2020 (in comparison to 2011).

3. Achievement of average profitability in agriculture over $25 \%$.

4. Increase of investment attractiveness of regional agri-industrial complex.

5. Twofold growth of income level in comparison to 2011.

6. Development of rural infrastructure in the region.

The program assumes housing construction in rural areas (105 thousand square meters by 2020), including 69.3 thousand square meters for young families; introduction of $661.3 \mathrm{~km}$ of gas distribution networks and $336 \mathrm{~km}$ of local water pipelines; construction of new educational, cultural and medical facilities (Government of Moscow Oblast, 2012).

Such ambitious targets are directed on improvement of living standards of rural people, which is necessary in order to push rural infrastructures as closer to the urban ones as possible. However, to be able to ensure the long-term sustainable development of rural areas the region should not only retain people in rural areas, but also attract them. There should be no gaps between urban and rural people in income level, social protection, and infrastructure support. As we have already outlined below, one of the major threats to sustainability of rural areas is their proximity to urban agglomerations, which absorb labour and other resources. That is why the strategic goal to achieve is not only infrastructural development itself through construction. There should be the transformation of the existing radial (centripetal) system of settlement into the multipolar one, when people do not have to move to big city (Moscow) seeking for employment opportunities, but obtain comparable income and related opportunities in 
the very place of their current location.

It is worthwhile to mention the second place of Leningrad Oblast in Agro2b Ranking on level of income in rural areas. Although Saint-Petersburg is threefold smaller than Moscow, Leningrad Oblast also has distinct features of a suburban region, where rural areas and rural population are gravitated by big urban agglomeration. The gap between income levels in urban and rural areas is not as severe in Leningrad Oblast, as it is in Moscow Oblast (89.73\% and $71.89 \%$ accordingly), however the average monthly wages per capita is much lower in comparison to Moscow (€620.66 and €842.18 accordingly in general, €556.95 and $€ 605.42$ accordingly in agriculture).

Leningrad Oblast is the Russia's biggest producer of eggs; it is ranked second among other regions of the country on poultry meat production, and third on trout production. Total volume of agricultural production of Leningrad Oblast in 2013 amounted to $€ 728.9$ $\operatorname{mln}(4.4 \%$ of GRP).

However, despite certain successes of those regions in the sphere of economic development, such suburban regions, as Moscow and Leningrad oblasts, as of A. Merzlov, have common problems in terms of rural development, related to land relations (land conflicts and higher prices for land in comparison to other regions), shortage of environmental and rural landscapes because of industrial and residential construction, and environmental problems (Merzlov et al., 2012). There are certain shortages, common for all regions of Russia, related to agricultural production incentives, support of local producers of agricultural and food commodities, especially small and medium ones, effective management in agriculture and rural development, encouragement of investments, promotion of innovation-driven growth of agricultural production, and effective utilization of existing natural and environmental resources (Lescheva, Ivolga, 2006). There are specific threats to sustainable rural development as well, caused by proximity to such big urban agglomerations as Moscow and SaintPetersburg. The main concerns of such "gravitational attraction" are:

1. exhaustion of the most qualified labour resources from rural areas in favour of cities;

2. conversion of traditional agricultural production into service industries and other nonagricultural types of economic activities;

3. absorption of rural areas by city suburbs and conversion of agricultural lands into lands acquired for public and commercial purposes;

4. growing social tensions because of huge migration inflows, particularly from neighbour countries of other languages, religions and cultures.

The abovementioned threats are additional to the existing weaknesses of agricultural production in Russia:

1. low rates of rehabilitation of natural and environmental resources and renovation of productive capacities in agriculture;

2. financial imbalance of agricultural production, caused by volatility of markets of 
agricultural commodities, raw materials and food, insufficient investments and low development of agricultural insurance;

3. shortage of labour of high qualification, caused by low living standards in rural areas.

In order to ensure sustainable rural development in such predominantly non-rural regions, as Moscow and Leningrad oblasts, in the conditions, when urban employment opportunities are much more attractive and beneficial for people, while rural way of life is less prestigious, when cities absorb traditional rural areas and lands are withdrawn from agriculture, is it necessary to implement a complex approach to rural policies both on federal and local levels (Ivolga, 2006). After all, proximity of rural areas to urban agglomerations is not only a threat, but also an advantage. There is always a huge market for local agricultural commodities and food (especially organic ones, which are becoming more and more demanded in big cities in Russia); bigger pool of distributors potential investors; easier access to newest developments and technologies to be introduced into agricultural production; far more developed infrastructure (especially transport and distribution) in comparison to other regions; great potential of rural tourism and other non-agricultural activities (cultural, ethnographical, etc.), which may attract people from neighbour cities to rural areas and bring alternative income opportunities.

There are already several sustainable settlement systems existing on the territory of Moscow Oblast (Table 6). They are being developed according to the dominant characters of functional territorial management in order to implement perspective territorial transformations in Moscow Oblast. Those transformations are directed on accelerated development of middle and peripheral parts of Moscow Oblast (its rural areas) and strengthening of circular and bisecant linkages between rural settlements themselves, without much involvement of central agglomeration: labour migration flows, economic, production, social, cultural and recreational relations of rural people (Government of Moscow Oblast, 2012).

Table 6. Sustainable settlement systems of Moscow Oblast: types and labour.

\begin{tabular}{|l|l|l|l|l|l|}
\hline \multirow{2}{*}{ Settlement system } & \multicolumn{1}{|c|}{ Type } & \multicolumn{1}{|c|}{ Pillar settlements } & \multicolumn{3}{|c|}{$\begin{array}{c}\text { Number of workplaces, } \\
\text { thousand }\end{array}$} \\
\cline { 4 - 6 } & & & $\mathbf{2 0 0 4}$ & $\mathbf{2 0 1 0}$ & $\begin{array}{c}\mathbf{2 0 2 0} \\
\text { (forecast) }\end{array}$ \\
\hline $\begin{array}{l}\text { Dolgoprudnensk-Kh- } \\
\text { imky-Krasnogorsk }\end{array}$ & Urban & $\begin{array}{l}\text { Lobnya, Dolgoprudny, } \\
\text { Khimky, Krasnogorsk }\end{array}$ & 164.5 & 175.1 & 192.5 \\
\hline $\begin{array}{l}\text { Mytyschy-Pushkino- } \\
\text { Schelkovo }\end{array}$ & Urban & $\begin{array}{l}\text { Mytyschy, Korolev, } \\
\text { Pushkino, Schelkovo }\end{array}$ & 317.5 & 335.2 & 364.5 \\
\hline Balashikha-Lyubertsy & $\begin{array}{l}\text { Recreational } \\
\text { urban }\end{array}$ & $\begin{array}{l}\text { Balashikha, Reutov, } \\
\text { Lyubertsy, Kotelniki }\end{array}$ & 260.6 & 277.0 & 304.6 \\
\hline Troitsk & $\begin{array}{l}\text { Recreational } \\
\text { urban }\end{array}$ & Troitsk, Pervomayskoe & 52.1 & 70.7 & 102.1 \\
\hline Odintsovo & Urban & Odintsovo, Marfino & 44.3 & 46.2 & 50.3 \\
\hline Istra-Zvevigorod & $\begin{array}{l}\text { Recreational } \\
\text { urban }\end{array}$ & Istra, Zvinigorod, Ruza & 130.6 & 155.0 & 195.6 \\
\hline
\end{tabular}




\begin{tabular}{|c|c|c|c|c|c|}
\hline \multirow{2}{*}{ Settlement system } & \multirow{2}{*}{ Type } & \multirow{2}{*}{ Pillar settlements } & \multicolumn{3}{|c|}{$\begin{array}{c}\text { Number of workplaces, } \\
\text { thousand }\end{array}$} \\
\hline & & & 2004 & 2010 & $\begin{array}{c}2020 \\
\text { (forecast) }\end{array}$ \\
\hline Klin & $\begin{array}{l}\text { Recreational } \\
\text { urban }\end{array}$ & Klin, Solnechnogorsk & 101.8 & 135.4 & 191.8 \\
\hline Yakhroma & $\begin{array}{l}\text { Recreational } \\
\text { rural }\end{array}$ & Dmitrov, Yakhroma & 28.5 & 38.6 & 55.5 \\
\hline Noginsk & Urban & Noginsk, Elektrostal & 201.1 & 228.0 & 273.1 \\
\hline $\begin{array}{l}\text { Vidnoe-Podolsk- } \\
\text { Ramenskoe }\end{array}$ & $\begin{array}{l}\text { Recreational } \\
\text { urban }\end{array}$ & $\begin{array}{l}\text { Scherbinka, Podolsk, } \\
\text { Vidnoe, Ramenskoe, } \\
\text { Zhukovsky, Gorki }\end{array}$ & 338.4 & 406.3 & 519.4 \\
\hline Naro-Fominsk & $\begin{array}{l}\text { Recreational } \\
\text { rural }\end{array}$ & $\begin{array}{l}\text { Naro-Fominsk, Apre- } \\
\text { levka }\end{array}$ & 62.6 & 72.7 & 89.6 \\
\hline $\begin{array}{l}\text { Volokolamsk- } \\
\text { Mozhaysk }\end{array}$ & $\begin{array}{l}\text { Recreational } \\
\text { rural }\end{array}$ & $\begin{array}{l}\text { Mozhaysk, Vereya, } \\
\text { Volokolamsk }\end{array}$ & 84.8 & 94.9 & 110.8 \\
\hline SergievPosad & $\begin{array}{l}\text { Recreational } \\
\text { rural }\end{array}$ & $\begin{array}{l}\text { SergievPosad, Dubna, } \\
\text { Dmitrov, Taldom }\end{array}$ & 206.7 & 222.5 & 249.7 \\
\hline Orekhovo-Zuevo & $\begin{array}{l}\text { Recreational } \\
\text { urban }\end{array}$ & $\begin{array}{l}\text { Orekhovo-Zuevo, } \\
\text { Lykino-Dulevo }\end{array}$ & 120.3 & 138.9 & 169.3 \\
\hline Kolomna & $\begin{array}{l}\text { Recreational } \\
\text { urban }\end{array}$ & $\begin{array}{l}\text { Kolomna, Egorievsk, } \\
\text { Voskresensk }\end{array}$ & 135.7 & 158.6 & 196.7 \\
\hline Chekhov & $\begin{array}{l}\text { Recreational } \\
\text { urban }\end{array}$ & Chekhov, Mikhnevo & 67.8 & 73.2 & 82.8 \\
\hline Zaoksk-Meschersk & $\begin{array}{l}\text { Recreational } \\
\text { rural }\end{array}$ & $\begin{array}{l}\text { Shatura, Kolomna, } \\
\text { Zaraysk, Roshal }\end{array}$ & 96.6 & 104.8 & 117.6 \\
\hline Serpukhov-Kashira & $\begin{array}{l}\text { Recreational } \\
\text { urban }\end{array}$ & $\begin{array}{l}\text { Serpukhov, Stupino, } \\
\text { Kashira, Kolomna }\end{array}$ & 196.1 & 216.5 & 251.1 \\
\hline \multicolumn{3}{|l|}{ Total } & 2610.0 & 2950.4 & 3517.0 \\
\hline
\end{tabular}

Source: Author's development based on (Government of Moscow Oblast, 2012).

There are five out of 18 settlement systems of Moscow Oblast referred to as recreational rural ones. Others have certain potentials in the sphere of recreational and rural way of development as well. Further development of such decentralized sustainable settlement systems will secure the natural and environmental resources, ensure territorial and functional development of rural areas, and restore their historical and cultural identities. Decentralization will let to reverse symptoms of continuing centripetal development of Moscow Oblast and provide new incentives to development of suburban rural areas.

\section{Conclusions}

As our analysis shows, many Russian experts (Lavrukhina, 2013; Lescheva, 2008; Bondarenko, 2011; Erokhin, Ivolga, 2012) acknowledge the systemic crisis in agriculture, which is partly a result of economic reforms, occurred in Russia in 1990-2000s, partly a consequence of global tendencies of growing population and issues of food security. Those issues stipulate increasing 
attention to rural territories as a source of agricultural commodities and food. However, current situation cannot be changed at once. Attractiveness of rural areas and effectiveness of agricultural production cannot be increased with just a bigger amount of investments. Rural way of life is like a social paradigm, which is developed under an influence of a whole set of non-economic factors: social, cultural, historical, ethnic, etc.

Perspectives of sustainable development of rural territories in Russia, in view of accumulated international and domestic experience, had been considered in two major directions:

1. Development of "agricultural cities". Experience of Belgorod Oblast of Russia shows that rural settlements get bigger with natural movement of people from peripheral districts of the region, as well as from neighbour regions and even countries. From one point of view, such attraction of people into rural areas serves as a driver for economic development. However, conversely, bigger rural settlements mean urbanization, reduction of agricultural producers and rural households, development of nonagricultural activities, and finally decrease of traditional agricultural production, which is always a threat to sustainable rural development. According to E. Lavrukhina, such way causes further "demographic shrinkage" of depopulation of peripheral rural districts (Lavrukhina, 2013).

2. De-urbanization and attraction of urban people to rural areas. This way requires development of related infrastructure in rural districts, including housing, social and medical facilities, employment opportunities, transport, etc. Rural districts may become attractive for resettlement only in case of insurance of living standards at least equal to urban ones. Such way has led many countries to development of "satellite rural settlements".

Both ways may be adjusted for Russia taking into account specifics of its particular regions. Our research of predominantly non-rural regions, gravitationally attracted by big urban agglomerations, has shown the perspectives of decentralization as an alternative way to ensure long-term sustainable development of rural areas. In such regions decreasing role of agriculture and related labour saving cause the necessity of diversification of rural economy and provision of alternative employment. As of today, rural people seek for such an alternative employment in the cities, while it should be available in the traditional places of their inhabitation. Development of decentralized sustainable settlement systems in the suburban rural areas may ensure strategic sustainable development of rural areas and secure their historical and cultural identities.

\section{References}

1. Agro2b (2014): Ranking of Regions of Russia on Quality of Life in Rural Areas and Level of Rural Development in 2013, Available at: http://agro2b.ru/ru/news/15095-Rejtingregionov-Komu-sele-zhit-horosho.html 
2. Bondarenko, L. (2011): Employment in Rural Areas and Diversification of Rural Economics, Economics of Agriculture of Russia, vol. 1, pp. 71-76.

3. Bronisz, U., Heijman, W., Miszczuk, A. (2008): Regional competitiveness in Poland: Creating an index, Jahrbuch für Regionalwissenschaft, vol. 28, no. 2, pp. 133-143.

4. Central Bank of the Russian Federation (2014): Euro/Ruble Exchange Rates. Available at: www.finnews.ru/cbr archive.php?nfromcur=EUR\&ndat $=1 \&$ nmon $=1 \&$ nyear $=2013 \&$ nd at $2=31 \&$ nmon $2=12 \&$ nyear $2=2013 \& x=43 \& y=8$

5. Cvijanovic, D., Vukovic, P. (2012): Role of marketing in tourism in Danube region, Institute of Agricultural Economics, Belgrade.

6. Erokhin, V., Ivolga, A. (2009): Regional competitiveness in the conditions of economic internationalization, Proceedings from the conference - Perspectives of development of agricultural economics during crisis, Stavropol, Russian Federation, pp. 287-290.

7. Erokhin, V., Ivolga, A. (2012): How to Ensure Sustainable Development of Agribusiness in the Conditions of Trade Integration: Russian Approach, International Journal of Sustainable Economies Management (IJSEM), vol. 1, no. 2, pp. 12-23.

8. Erokhin, V., Ivolga, A., Andrei, J., et al. (2014): Contemporary Issues of Sustainable Rural Development: International Approaches and Experiences of Eastern Europe and Russia, monograph, AGRUS of Stavropol State Agrarian University, Stavropol, Russia.

9. Government of Moscow Oblast (2012): Long-term Target Program of Moscow Oblast on Development of Agriculture and Regulation of Markets of Agricultural Commodities, Raw Materials and Food in 2013-2020, Moscow, Russia.

10. Heide, C., Heijman, W. (eds), (2012): The Economic Value of Landscapes, monograph, Routledge Studies in Ecological Economics, Routledge, London, UK.

11. Heijman, W., Schipper, R. (2010): Space and Economics: An introduction to regional economics, Mansholt Publication Series, vol. 7, Wageningen Academic Publishers, Wageningen, the Netherlands.

12. Ivolga, A. (2006): Redistribution of Agricultural Lands as the Major Element of Rural Development, Russian Entrepreneurship, vol. 8, pp. 124-129.

13. Ivolga, A., Uryadova, T. (2010): Organizational and Economic Problem of Effective Involvement of Agricultural Lands into Civil Turnover, Russian Economic Internet Journal, vol. 2, pp. 120-127.

14. Ivolga, A., Belak, I. (2013): Problems of Development and Perspectives of Tourism Potential in Caucasian Mineral Waters, Proceedings from the conference - Sustainable development of tourist market: international practices and experiences of Russia, STGAU, Stavropol, Russian Federation, pp. 68-74.

15.Ivolga, A., Mikhaylova, K. (2013): Approaches to Sustainable Regional Development by means of Utilization of Tourist and Recreational Potential, Proceedings from the 
conference - Sustainable development of tourist market: international practices and experiences of Russia, STGAU, Stavropol, Russian Federation, pp. 39-47.

16. Ivolga, A., Erokhin, V. (2013): Tourism as an Approach to Sustainable Rural Development: Case of Southern Russia, Economics of Agriculture, IAE Belgrade, vol. 60, no. 4, pp. 789-800.

17. Jelocnik, M., Ivolga, A. (2012): International Approaches to Analysis of Regional Agricultural Potential: Cases of Stavropol Region and Republic of Serbia, Proceedings from the conference - Actual Problems of Agribusiness Development in the Conditions Economic Modernization, STGAU, Stavropol, Russia, pp. 10-16.

18. Kundius, V., Chermyanina, V. (2011): Problems and Perspectives of Rural Tourism in the Region, Bulletin of the Altay State University, vol. 2, p. 289.

19. Lavrukhina, E. (2013): Social Resources of Rural Development in the Russian Federation (Sociological Analysis), Unpublished doctoral dissertation, The Russian Presidential Academy of National Economy and Public Administration, Moscow.

20. Lescheva, M., Ivolga, A. (2006): Problems of Agricultural Land Turnover in Agriculture, Bulletin of Higher Educational Institutions, North-Caucasus Region, Social Sciences Seria, vol. S24, pp. 49-21.

21. Lescheva, M. (2007): Agri-industrial Integration in the Conditions of Russia's Accession into the WTO, International Agricultural Magazine, vol. 5, p. 6.

22. Lescheva, M. (2008): Problems of Development of Integration Processes in Contemporary Agriculture, Economic Strategies, vol. 1, pp. 138-144.

23. Merzlov, A. et al (2012): Introduction to Sustainable Rural Development: Major Definitions and Theoretical Framework, monograph, Russian Timiryazev State Agrarian University, Moscow, Russia.

24. Merzlov, A., Ovchintseva, L., Popova, O. (2012): Regional Experience of Elaboration of Programs of Sustainable Rural Development, monograph, Rosinformagrotekh, Moscow, Russia.

25. Rosstat (2012): Regions of Russia. Social and Economic Indicators: statistic compilation, Moscow, Russia.

26. Rosstat (2014): Inflation in the Russian Federation, Available at: http://inflationinrussia. com/inflation table.aspx

27. Rusinova, O. (2011): The Efficiency Rating for the Use of Resource Potential of Social and Economic Development as to Rural Territories of an Agrarian Region, Bulletin of the Udmurtia University, Economics and Law, vol. 3, pp. 48-52.

28. State Council of the Russian Federation (2014): Report on Sustainable Development of Rural Territories of the Russian Federation, Moscow, Council under the President of the Russian Federation on Implementation of Priority National Projects and Demographic Policy. 
29. Trukhachev, A., Lescheva, M. (2010): Integration Processes in Innovation Development of Agri-Industrial Complex, Achievements of Science and Technology in Agriculture, vol. 9, pp. $5-7$.

30. Vuković, P., Kljajić, N., Arsić, S. (2012): Multifunctional Agriculture as an Assumption and a Condition for Rural Development in Serbia-Special Turn to Rural Tourism, International Journal of Sustainable Economies Management, vol. 1, no. 2, pp. 24-32.

31. Wiggins, S., Proctor, S. (2001): How special are rural areas? The economic implications of location for rural development, Development Policy Review, vol. 19, no. 4, Blackwell Publishing, London, Great Britain. 